\title{
IMPLEMENTASI LESSON STUDY PADA INTEGRASI KURIKULUM 2013 SEBAGAI DAYA DUKUNG KOMPETENSI PEDAGOGIK GURU MI MA'ARIF KUMPULREJO 02 KOTA SALATIGA
}

\author{
Laily Syafa'ah, Taufiqur Rohman \\ IAIN SALATIGA \\ Syafalaili93@gmail.com,rohmantaufiqur93@gmail.com
}

\begin{abstract}
Abstrak
Penelitian ini bertujuan untuk mendeskripsikan keterlaksanaan Lesson Study sebagai daya dukung kompetensi pedagogik guru MI Ma'arif Kumpulrejo 02 Salatiga, serta kemampuan mengintegrasikan Kurikulum 2013 dalam pelatihan program Lesson Study. Penelitian ini merupakan penelitian tindakan dengan pendekatan deskriptif kualitatif dengan subjek penelitian yaitu kepala sekolah dan dewan guru serta pengawas MI Kota Salatiga dengan jumlah 1 kepala sekolah ,3 dewan guru dan 2 peserta didik serta pengawas MI Kota Salatiga. Pelaksanaan Lesson Study ditekankan pada 3 tahap yaitu plan (merencanakan atau merancang), Do (melaksanakan), dan See (mengamati, dan sesudah itu merefleksikan hasil pengamatan). Pelaksanaan Lesson Study di MI Ma'arif Kumpulrejo 02 masih perlu pendampingan lebih lanjut dalam pembuatan RPP sesuai kurikulum 2013 dengan mengingat urgensi pendidikan karakter yang terintegrasi dalam mata pelajaran. Lesson Study harus dikembangkan dengan melibatkan guru-guru, serta pakar dan praktisi pendidikan dari instansi lain untuk menambah khazanah wawasan metode dan strategi pembelajaran yang lebih kompleks. Lesson Study juga membantu guru menerima tunjangan kesejahteraan, karena program Lesson Study mampu membentuk kompetensi guru yang unggul. Program Lesson Study salah satu wadah bagi guru dalam menjawab perkembangan zaman yang semakin kompleks, Lesson study mampu menjadi daya dukung bagi guru dalam memperjuangkan kesehteraannya serta membantu guru dalam menjawab tantangan zaman dan sebagai daya dukung terhadap kompetensi lulusan serta kualitas lembaga pendidikan. Kendala yang terjadi dalam proses Lesson Study di MI Ma'arif Kumpulrejo 02 Salatiga adalah sebagai berikut: Kurangnya motivasi guru dalam mengembangkan program Lesson Study, Kurangnya Pendanaan program Lesson Study di MI Ma'arif Kumpulrejo 02, Sarana dan Prasarana di MI Ma'arif Kumpulrejo 02 Kurang lengkap, Sulitnya Penyusunan jadwal pelaksanaan program Lesson Study di MI Ma'arif Kumpulrejo 02, Pendokumentasian kegiatan Lesson Study di MI Ma'arif Kumpulrejo 02 Kurang lengkap, serta Kurangnya daya dukung Yayasan dan Kementerian Agama
\end{abstract}

Kata Kunci: Lesson study, Integrasi kurikulum 2013, Peningkatan kompetensi pedagogik guru.

MUBTADI: Jurnal Pendidikan Ibtidaiyah

Vol. 2 No. 2, Januari - Juni 2021

P - ISSN : $2715-7067$

E - ISSN : 2720 - 8850 


\begin{abstract}
This study aims to describe the implementation of Lesson Study as the supporting capacity of the pedagogical competence of MI Ma'arif Kumpulrejo 02 Salatiga teachers, as well as the ability to integrate the 2013 Curriculum into the Lesson Study program training. This research is an action research with a qualitative descriptive approach with the research subjects, namely the principal and the board of teachers as well as the supervisor of MI Salatiga City with the total of 1 school principal, 3 teacher councils and 2 students and supervisors of MI City of Salatiga. The implementation of Lesson Study is emphasized on 3 stages, namely plan (plan or design), Do (implement), and See (observe, and after that reflect on the results of the observations). The implementation of Lesson Study at MI Ma'arif Kumpulrejo 02 still needs further assistance in making RPP according to the 2013 curriculum keeping in mind the urgency of integrated character education in the subject. Lesson Study should be developed by involving teachers, as well as education experts and practitioners from other agencies to add to their knowledge of more complex learning methods and strategies. Lesson Study also helps teachers receive welfare allowances, because the Lesson Study program is able to form superior teacher competencies. The Lesson Study Program is a forum for teachers to respond to increasingly complex developments in the era, Lesson study is able to be a supporting capacity for teachers in fighting for their health and helping teachers in responding to the challenges of the times and as a support capacity for graduate competencies and the quality of educational institutions. The obstacles that occurred in the Lesson Study process at MI Ma'arif Kumpulrejo 02 Salatiga were as follows: Lack of teacher motivation in developing the Lesson Study program, Lack of funding for the Lesson Study program at MI Ma'arif Kumpulrejo 02, Facilities and Infrastructure at MI Ma'arif Kumpulrejo 02 Incomplete, Difficulty in compiling a schedule for the implementation of the Lesson Study program at MI Ma'arif Kumpulrejo 02, Documenting Lesson Study activities at MI Ma'arif Kumpulrejo 02 Incomplete, and Lack of support capacity of the Foundation and the Ministry of Religion
\end{abstract}

Keywords:Lesson study, 2013 curriculum integration, Improvement of teacher pedagogical competence.

\title{
PENDAHULUAN
}

Tantangan masa depan yang begitu cepat baik dalam kemajuan teknologi informasi, masalah lingkungan hidup, kebangkitan industri kreatif dan budaya, pengaruh teknosains serta masih banyak tantangan yang dihadapi oleh generasi milenial berbeda sesuai dengan masanya. Sehingga pemerintah melakukan upaya berupa pengembangan kurikulum setiap beberapa tahun. Kurikulum 2013 merupakan kurikulum yang terintegrasi, maksud integrasi adalah sebuah kurikulum yang mengintegrasikan keterampilan, tema, 
konsep dan topik yang melibatkan beberapa disiplin ilmu untuk memberikan pengalaman bermakna dan luas kepada peserta didik.

Tugas utama guru adalah mendidik, mengajar, membimbing, mengarahkan, melatih, menilai, dan mengevaluasi setiap peserta didik. Oleh sebab itu, profesi guru sangat lekat dengan integritas dan kepribadian, bukan hanya sekedar mentransfer ilmu pengetahuan kepada peserta didiknya, tugas guru sebagai pendidik adalah menanamkan nilai-nilai dasar pengembangan karakter peserta didik dalam kehidupannya, termasuk dalam pemanfaatan kemajuan teknologi informasi secara bijak serta sebagai inspirator bagi anak didiknya.

Lembaga penyelenggara pendidikan memiliki tugas utama dalam menyusun perangkat mata pelajaran dan program pendidikan yang akan diberikan kepada peserta pelajaran dalam satu periode jenjang pendidikan.

Penyusunan perangkat pembelajaran ini akan disesuaikan dengan keadaan dan kemampuan setiap jenjang pendidikan dalam penyelenggaraan pendidikan menyesuaikan kebutuhan lapangan pekerjaan. Maka perlu ada perubahan berkala yang disesuaikan dengan maksud dan tujuan dari sistem pendidikan yang dilaksanakan.

Kompetensi yang harus dimiliki oleh guru ada empat kompetensi, yaitu kompetensi pedagogik, kepribadian, sosial serta kompetensi profesional. ${ }^{1}$ Sebagaimana dikatakan dalam lampiran peraturan Menteri pendidikan Nasional Nomor 16 Tahun 2007 tentang Standar Kualifikasi Akademik dan Kompetensi Guru, bahwa guru harus mampu melakukan tindakan reflektif untuk peningkatan kualitas pembelajaran ${ }^{2}$. Masih rendahnya tingkat kompetensi pedagogik guru saat ini disebabkan oleh faktor-faktor yang berasal dari internal guru itu sendiri dan faktor lainnya yang berasal dari luar.

Peneliti mendapatkan data bahwa MI Ma'arif Kumpulrejo 02 Kota Salatiga adalah salah satu sekolah Madrasah Ibtidaiyah pertama di kota Salatiga yang ditunjuk untuk menyelenggarakan pendidikan berbasis kurikulum 2013, meskipun sudah melaksanakan kurikulum 2013 sejak tahun 2014 pelaksanaannya bertahap yang diawali dengan kelas 1 dan IV, selanjutnya kelas II dan V, sedangkan kelas III dan VI baru diterapkan 2 tahun terakhir. Sehingga selama tahun 2014 sekolah terus-menerus mencoba menyesuaikan segala perubahan atau revisi penyempurnaan kurikulum. Pemerintah Indonesia khususnya Menteri Pendidikan dan Kebudayaan pada tahun 2018 telah melakukan revisi beban tuntutan pada out put peserta didik. Sehingga seorang guru sangat dituntut melalui peraturan Menteri pendidikan Nasional Nomor 16 Tahun 2007 tentang Standar Kualifikasi Akademik dan Kompetensi Guru, bahwa guru harus mampu melakukan tindakan reflektif

${ }^{1}$ Departemen Pendidikan Nasional, Undang-undang No. 14 tahun 2005 Pasal 10 ayat (1) tentang Guru dan Dosen, Jakarta: Depdiknas.2005.

${ }^{2}$ Ninik Sumiarsi, “Analisis Kompetensi Pedagogik dan Pengembangan Pembelajaran Guru SD Negeri 041 Tarakan”, Jurnal Pendidikan dan Pengembangan Pendidikan, Vol. 3, No.1 (2015), 99-104. 
untuk peningkatan kualitas pembelajaran dalam merespon perkembangan yang sangat cepat.

Kurangnya fasilitas dan perhatian Kementrian Agama berkaitan pelatihan kurikulum 2013 terhadap guru di lingkungan Madrasah adalah salah satu kendala pelaksanaan kurikulum 2013 di MI Kumpulrejo 02, perubahan yang selalu terjadi menuntut kompetensi pedagogik guru untuk mampu menguasai dan merespon semua perkembangan. Dalam merespon tuntutan bagi guru MI Kumpulrejo 02 agar mampu mengintegrasikan kurikulum 2013 dengan cara melaksanakan Lesson Study. Lesson Study merupakan kegiatan yang memberikan kesempatan kepada guru untuk melakukan refleksi dan evaluasi terhadap paradigma pengajarannya bekerjasama dengan guru lain atau Dosen di perguruan tinggi ${ }^{3}$.

Berdasarkan uraian tersebut, penulis tertarik untuk melakukan penelitian lebih lanjut mengenai kompetensi pedagogik guru dengan judul: "Implementasi Lesson Study pada integrasi kurikulum 2013 sebagai daya dukung kompetensi pedagogik guru MI Ma'arif Kumpulrejo 02 Kota Salatiga".

\section{METODE}

Penelitian ini merupakan penelitian kualitatif, yakni penelitian yang bertujuan untuk memahami fenomena yang terjadi pada subyek penelitian, seperti perilaku, persepsi, motivasi, tindakan secara menyeluruh dan dengan cara deskripsi.

Sumber yang memuat informasi atau data tersebut yaitu Kepala Madrasah, guru MI Ma'arif Kumpulrejo 02 Kota Salatiga dengan jumlah guru 3 guru sebagai guru model, yaitu wali kelas IV A, wali kelas IV B dan wali kelas V A, serta 3 - 5 observer diantaranya teman sejawat dan dokumentasi tentang pelaksanaan Lesson Study di MI Ma'arif Kumpulrejo 02 Salatiga.

Pengumpulan data dengan menggunakan tiga metode berikut:

1. Obseravasi

Observasi adalah pengamatan dan pencatatan secara sistematis atas fenomena-fenomena yang diteliti. Observasi dilakukan untuk mengamati proses pelaksanaan Lesson Study di MI Ma'arif Kumpulrejo 02 tentang implementasi Lesson Study sebagai daya dukung kompetensi pedagogik guru di MI Ma'arif Kumpulrejo 02 Kota Salatiga.

2. Wawancara

${ }^{3}$ Marsigit, "Mathematics Teachers' Profesional Development through Lesson Study in Indonesia", Eurasia Journal of Mathematics, Science \& technology Education, Vol 3, No.2 (2007), 141-144. 
Wawancara adalah sebuah dialog yang dilakukan oleh pewawancara untuk memperoleh informasi dari terwawancara. Wawancara dilakukan secara langsung antara peneliti dengan subyek yang diteliti. Wawancara yang dilakukan dengan menggunakan pedoman wawancara tentang pelaksanaan Lesson Study kepada kepala sekolah, guru dan pengawas MI Kota Salatiga tentang Implementasi, Lesson Study, Kompetensi Pedagogik dan Daya Dukung Lesson Study.

3. Dokumentasi

Dokumentasi adalah metode yang menggunakan data yang sudah tersedia yang berupa data verbal maupun nonverbal. Dokumentasi berupa data yang terdapat pada indeks prestasi siswa, surat-surat, catatan harian, jurnal, kenang-kenangan, laporan-laporan, dan sebagainya untuk kelengkapan data penelitian.

Teknik analisis data yang digunakan dalam penelitian ini adalah mengacu pada konsep Milles dan Huberman (1992: 20) yaitu interactive model yang mengklasifikasikan analisis data dalam tiga langkah, yaitu:

1. Reduksi data (Data Reduction)

Reduksi data yaitu suatu proses pemilihan, pemusatan perhatian pada penyederhanaan, pengabstrakan dan transformasi data kasar yang muncul dari catatan-catatan tertulis di lapangan. Reduksi data berupa hasil wawancara terhadap subjek.

Data yang dikumpulkan melalui proses wawancara dengan pihak terkait seperti melaksanakan wawancara dengan kepala sekolah dan dewan guru di sekolah tersebut. Wawancara dilaksanakan dengan menggali informasi tetang pelaksanaan lesson study di MI Ma'arif Kumpulrejo 02 serta dampak dari program tersebut. Dalam pelaksanaannya peneliti melakukan wawancara dari satu responden satu ke responden lainnya, dari hasil wawancara dipadukan untuk menarik kesimpulan.

2. Penyajian Data (Display Data)

Data ini tersusun sedemikian rupa sehingga memberikan kemungkinan adanya penarikan kesimpulan dan pengambilan tindakan. Adapun bentuk data digunakan dalam bentuk teks naratif.

3. Penarikan Kesimpulan

Dalam penelitian ini akan diungkap mengenai makna dari data yang dikumpulkan. Dari data tersebut akan diperoleh kesimpulan yang tentative, kabur kaku dan meragukan, sehingga kesimpulan tersebut perlu diverifikasi. 
Verifikasi dilakukan dengan melihatkembali reduksi data maupun display data sehingga kesimpulan yang diambil tidak menyimpang.

Triangulasi sumber berarti bahwa peneliti menguji kredibilitas data dengan mengecek dan membandingkan data dari satu orang informan dengan data dari informan lain. Triangulasi sumber memungkinkan peneliti untuk melakukan pengecekan ulang serta melengkapi informasi yang diperoleh. Dalam menarik kesimpulan peneliti melakukan pembandingan data hasil wawancara satu responden satu dengan responden lainnya, hal ini juga didukung dengan data lembaga yang ada.

Tringulasi pada penelitian ini untuk melakukan crosscheck data antar informan yang terkadang terjadi akibat adanya pengaruh subjektivitas, kepentingan. Triangulasi teknik dilakukan dengan cara mengecek (membandingkan ) data kepada informan (sumber)yang sama dengan teknik yang berbeda. Pada pelaksanaannya menggunakan salah satu atau gabungan dari kedua terknik triangulasi. ${ }^{4}$

\section{HASIL PENELITIAN DAN PEMBAHASAN}

A. IMPLEMENTASI LESSON STUDY PADA INTEGRASI KURIKULUM 2013 DI MI MA'ARIF KUMPULREJO 02

1. Program Lesson Study di MI Ma'arif Kumpulrejo 02 Salatiga

Lembaga pendidikan memiliki cara masing-masing dalam meyakinkan masyarakat untuk mempercayakan pedidikan bagi putra putrinya. Salah satu hal paling menentukan kepercayaan masyarakat adalah kualitas pendidikan lembaga tersebut, dan cermin utama suatu kualitas pendidikan adalah pada kompetensi guru yang dimiliki. MI Ma'arif Kumpulrejo 02 merupakan lembaga yang harus terus berinovasi untuk mampu meyakinkan masyarakat di tengah beragamnya lembaga pendidikan di Kota Salatiga.

Program peningkatan di bidang prestasi, sarana prasarana, kualitas pendidik semua telah menajdi prioritas pengembangan di MI Ma'arif Kumpulrejo 02. Program lesson study merupakan salah satu solusi program yang dicanangkan oleh MI Ma'arif Kumpulrjo 02.

a. Rapat Koordinasi Penyusunan Program Lesson Study

Rapat Koordinasi dilaksanakan untuk menentukan kesepakatan di awal menentukan jadwal, pendanaan serta ketentuan lainnya. Pihak - pihak yang terlibat dalam Rapat Koordinasi penyusunan program Lesson Study adalah kepala sekolah,

${ }^{4}$ Sugiyono, Metode Penelitian Pendidikan: Pendekatan, Kuantitatif, Kualitatif, dan R7D, Bandung: alfabeta, 365-377. 
dewan guru dan karyawan. Sedangkan dalam proses pelaksanaannya akan banyak yang dilibatkan seperti halnya kepala sekolah, dewan guru, karyawan, komite, pengawas serta akademisi di bidang pendidikan

Cita-cita pemerintah agar guru menjadi agen perubahan adalah dengan membekali guru dengan segudang kompetensi agar mampu membuat siswa tertarik untuk selalu belajar penuh semangat dan akhirnya sukses dalam pendidikannya. Guru yang mampu menyelesaikan persoalan-persoalan di kelas dan membimbing peserta didik dengan sabar itulah sejatinya guru.

\section{b. Program Lesson Study MI Ma'arif Kumpulrejo 02 Kota Salatiga}

Program Lesson Study dikelola secara bersama dengan para guru dan karyawan, namun dalam pelaksanaan program yang disusun ada seorang guru yang ditunjuk sebagai koordinator pelaksana program Lesson Study di MI Ma'arif Kumpulrejo 02. Berikut yang disampaikan kepala Madrasah Ibu Istiqah yaitu:

"Program kegiatan disusun dan disepakati bersama saat rapat awal tahun pelajaran sebagai upaya peningkatan kompetensi guru dalam pelayanan kepada peserta didik serta membantu mempermudah mendapatkan tunjangan sertifikasi bagi guru yang belum sertifikasi. Untuk memudahkan koordinasi dan pelaksanaan maka ditunjuk salah satu guru yang bertanggungjawab dalam mengkoordinasi pelaksanaan program Lesson Study di MI ma'arif Kumpulrejo". 5

\section{c. Program Lesson Study MI Ma'arif Kumpulrejo 02 Kota Salatiga}

Program Lesson Study dikelola secara bersama dengan para guru dan karyawan, namun dalam pelaksanaan program yang disusun ada seorang guru yang ditunjuk sebagai koordinator pelaksana program Lesson Study di MI Ma'arif Kumpulrejo 02. Berikut yang disampaikan kepala Madrasah Ibu Istiqah yaitu:

"Program kegiatan disusun dan disepakati bersama saat rapat awal tahun pelajaran sebagai upaya peningkatan kompetensi guru dalam pelayanan kepada peserta didik serta membantu mempermudah mendapatkan tunjangan sertifikasi bagi guru yang belum sertifikasi. Untuk memudahkan koordinasi dan pelaksanaan maka ditunjuk salah satu guru yang bertanggungjawab dalam mengkoordinasi pelaksanaan program Lesson Study di MI ma’arif Kumpulrejo". 6

\footnotetext{
${ }^{5}$ Wawancara dengan Ibu IRN kepala sekolah MI Ma'arif Kumpulrejo 02 pada tanggal 11 November 2019.

${ }^{6}$ Wawancara dengan Ibu IRN kepala sekolah MI Ma'arif Kumpulrejo 02 pada tanggal 11 November 2019.
} 
Adapun program tahunan kegiatan Lesson Study di MI Ma'arif Kumpulrejo 02 Salatiga adalah sebagai berikut:

\begin{tabular}{|l|l|l|}
\hline Waktu & Kegiatan & Keterangan \\
\hline Maret & Lesson Study tahap 1 & Minggu 2 \\
\hline Juli & Lesson Study tahap 2 & Minggu 3 \\
\hline September & Lesson Study tahap 3 & Minggu 2 \\
\hline Desember & Lesson Study tahap 4 & Minggu 3 \\
\hline
\end{tabular}

Tabel 2.1 tabel program pelaksanaan Lesson Study

Untuk setiap program pelaksanaan ditentukan beberapa coordinator sebagai pelaksana kegiatan Lesson Study di MI Ma'arif Kumpulrejo 02. Selain itu hal yang harus dipertimbangkan dalam kegiatan ini adalah menentukan waktu yang harus sesuai dengan kalender pendidikan di lingkungan kementerian Agama serta yayasan dan dinas pendidikan di Kota Salatiga.

Sebagaimana yang disampaikan oleh ketua koordinator program Lesson Study di MI Ma'arif Kumpulrejo 02 kota Salatiga:

"Penyusunan jadwal program Lesson Study disesuaikan dengan kalender pendidikan di lingkungan Kementerian Agama, sehingga pelaksanaannya tidak mengganggu pelayanan pembelajaran kepada siswa diMadrasah"7

Pelaksanaan Lesson Study ditekankan pada 3 tahap yaitu plan (merencanakan atau merancang), Do (melaksanakan), dan See (mengamati, dan sesudah itu merefleksikan hasil pengamatan). ${ }^{8}$

Strategi kepala sekolah dalam meningkatkan kualitas pendidikan, antara lain sebagai berikut yang dipaparkan kepala sekolah MI Ma'arif Kumpulrejo 02:

"Ide mengenai pelaksaan Lesson Study ini sederhana dan singkat namun didalam pelaksanaan Lesson Study menuntut komitmen yang tinggi dari sekelompok guru dan perlu penyediaan waktu dan pemikiran kreatif pendidik. Namun melalui kegiatan Lesson Study diyakini akan terbentuk pribadi-pribadi yang berkarakter karena kegiatan Lesson Study ini melatih guru untuk rendah hati, dan mau bekerja keras, bertekun, terbuka terhadap pendapat orang lain, dan disiplin". 9

7 Wawancara dengan Ibu TM selaku ketua koordinator program Lesson Study di MI Ma'arif Kumpulrejo 02 pada tanggal 11 Desember 2019.

8 Ibrohim, Apa, Mengapa dan Bagaimana Lesson Study: Pola Alternatif untuk meningkatkan Efektivitas Praktik Pengalaman Lapangan (PPL) Mahasiswa Calon Pendidik. Makalah disajikan dalam Workshop Pembimbing PPL Berbasis Lesson Study di FS UM, Tanggal 26 Januari 2010.

${ }^{9}$ Wawancara dengan Ibu IRN kepala sekolah MI Ma'arif Kumpulrejo 02 pada tanggal 3 Desember 2019. 
Menurut Baba (2007), Lesson Study merujuk pada proses yang dilakukan guru secara progresif berusaha untuk meningkatkan metode pembelajaran mereka dengan cara bekerjasama dengan guru-guru lainnya.

Guru "digugu lan ditiru" kalimat peribahasa yang sering didengar oleh telinga ketika mendengar nama Guru disebut. Sebagai tenaga professional, guru memiliki kode etik dalam melaksanakan tugas dan fungsinya, memiliki objek layanan yang tetap dan diakui karena jasanya di masyarakat. ${ }^{10}$ Profesi guru menuntut adanya tingkat pendidikan keguruan yang memadai, menuntut keterampilan yang berdasarkan konsep dan teori ilmu pengetahuan yang mendalam, menekankan sesuatu keahlian dalam bidang tertentu, memungkinkan perkembangan sejalan dengan dinamika kehidupan.

2. Pelaksanaan Lesson Study di MI Ma'arif Kumpulrejo 02

Guru Sebagai pendidik professional, dituntut untuk menguasai seperangkat pengetahuan, keterampilan dan perilaku yang harus dimiliki, dihayati, dan dikuasai oleh guru dalam melaksanakan tugas keprofesionalnya. ${ }^{11}$ Sebagaimana tercantum pada teori tersebut, maka sangat relevan apabila diaplikasikan pada upaya MI Ma'arif dalam meningkatkan kualitas pendidik, dari Ibu Istiqah pula peneliti dapat mengetahui sisi-sisi yang dapat dibenahi. Adapun hasil penelitian yang dilakukan oleh peneliti tentang Lesson Study dalam meningkatkan kompetensi pedagogik guru. Sebagaimana yang diungkapkan oleh Ibu Istiqah, S.Pd selaku kepala sekolah di MI Ma'arif Kumpulrejo 02:

"Menjalankan kepemimpinan sebagai Kepala Madrasah telah membentuk konsep diri untuk senantiasa memberikan pelayanan bukan hanya kepada peserta didik dan masyarakat, akan tetapi juga rekan kerja sebagai tim pelaksana tujuan dan cita-cita kepemimpinan yang di konsep. Keberhasilan suatu lembaga pendidikan utamanya ada di tangan para guru yang berinteraksi dengan peserta didik. Dengan terciptanya guru yang berkompetensi akan melahirkan peserta didik yang berkompeten pula". ${ }^{12}$

Dalam mengimplementasikan upaya peningkatan kompetensi pedagogik guru dalam meningkatkan kualitas pendidikan, tentunya harus dibuat rancangan terlebih dahulu dan ditetapkan program-program yang ada di MI Ma'arif

\footnotetext{
${ }^{10}$ Dwi Ariyani, Guru Sadar Tantangan Zaman, Sukoharjo: CV.Farishma Indonesia, 2018,1-2.

11 Mahmudi, Mengembangkan Kompetensi Guru melalui Lesson Study. Forum Kependidikan, Volume 28, nomor 2 Maret 2009.

${ }^{12}$ Wawancara dengan Ibu IRN kepala sekolah MI Ma'arif Kumpulrejo 02 pada tanggal 3 Desember 2019.
} 
Kumpulrejo 02. Kepala Sekolah bersama dewan guru merancang suatu program yang dapat dilaksanakan dengan mengintegrasikan kurikulum 2013 untuk membekali guru terhadap perkembangan dunia pendidikan.

"Keputusan dalam menyusun suatu program kegiatan dalam rangka peningkatan mutu lembaga pendidikan MI Ma'arif Kumpulrejo 02 melalui proses musyawarah antara kepala sekolah dengan dewan guru, serta komite sekolah. Program Lesson Study diterapkan di MI Ma'arif Kumpulrejo 02 adalah salah satu bentuk usaha dalam meningkatkan mutu lembaga melalui peran guru di Madrasah"13

Kegiatan Lesson Study di MI Ma'arif Kumpulrejo 02 sudah terlaksana hampir 3 tahun terakhir, dalam pelaksanaannya guru memperoleh pengalaman yang baru, hal ini karena dalam pelaksanaan Lesson Study mengangkat masalah satu dengan masalah yang lain, selain itu adanya wadah sebagai bentuk problem solving atas segala masalah yang timbul dalam pembelajaran di kelas masing-masing.

Tahapan pola pelaksanaan Lesson Study. ${ }^{14}$ Tahapan awal adalah perencaan (Plan) dilakukan secara kolaboratif oleh beberapaorang pendidik yang termasuk dalam satu kelompok Lesson Study. Selanjutnya guru menyusun RPP, dalam kegiatan ini guru berbagi ide menyempurnakan rancangan pembelajaran yang sudah disusun guru model untuk menghasilkan cara pengorganisasian bahan ajar, proses pembelajaran, maupun penyiapan alat bantu pembelajaran yang dianggap paling baik. Semua komponen yang tertuang dalam rancangan pembelajaran ini kemudian disimulasikan sebelum dilaksanakan dalam kelas. Pada tahap ini juga ditetapkan prosedur pengamatan dan instrumen yang diperlukan dalam pengamatan.

Tahap pelaksanaan (Do) dimaksudkan untuk menerapkan rancangan pembelajaran yang telah direncanakan. Salah satu anggota kelompok berperan sebagai guru model dan anggota kelompok lainnya mengamati. Guru model adalah guru yang ditunjuk dalam forum untuk mempraktikan rancangan pembelajaran yang disusun, namun yang berjalan di MI Ma'arif Kumpulrejo 02 langsung menunjuk guru yang merasa memiliki masalah tersebut, khususnya guru kelas yang materi dan tingkatan kelasnya diangkat dalam Lesson Study tersebut dengan tujuan

${ }^{13}$ Wawancara dengan Ibu IRN kepala sekolah MI Ma'arif Kumpulrejo 02 pada tanggal 3 Desember 2019.

${ }^{14}$ Prof. Dra. Herawati Susilo, M.Sc., Ph. D, Lesson Study Sebagai Sarana Meningkatkan Kompetensi Pendidik, Makalah disajikan dalam seminar dan Lokakarya PLEASE 2013 di Sekolah Tinggi Theologi Aletheia, tanggal 9 Juli 2013. 
agar guru kelas dapat mengaplikasikan langsung apa yang dipraktikan dalam Lesson Study.

Fokus pengamatan diarahkan pada kegiatan belajar siswa dangan berpedoman pada prosedur dan instrumen yang telah disepakati pada tahap perencanaan, bukan pada penampilan pendidik yang sedang bertugas mengajar. Selama pembelajaran berlangsung, para pengamat tidak diperkenanakan mengganggu proses pembelajaran walaupun mereka boleh merekamnya dengan kamera video atau kamera digital. Tujuan utama kehadiran pengamat adalah belajar dari pembelajaran yang sedang berlangsung.

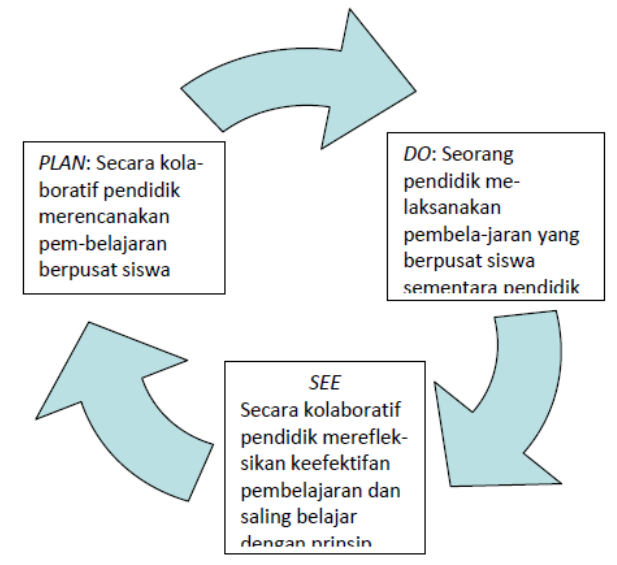

Gambar 2.1. Siklus Pengkajian Pembelajaran dalam Lesson Study

Tahap ketiga adalah pengamatan dan refleksi (See) dimaksudkan untuk menemukan kelebihan dan kekurangan pelaksanaan pembelajaran. Pendidik yang bertugas sebagai guru model mengawali diskusi dengan menyampaikan kesan dan pemikirannya mengenai pelaksanaan pembelajaran. Kesempatan berikutnya diberikan kepada pendidik yang bertugas sebagai pengamat. Selanjutnya pengamat dari luar juga mengemukakan apa Lesson Study yang dapat diperoleh dari pembelajaran yang baru berlangsung. Kritik dan saran disampaikan secara bijak tanpa merendahkan atau menyakiti hati pendidik yang membelajarkan, semuanya demi perbaikan praktik ke depan.

Gambaran umum pelaksanaan program Lesson Study di MI Ma'arif Kumpulrejo 02 berdasarkan koordinator pelaksananya adalah sebagai berikut:

"Pada dasarnya kegiatan Lesson Study di MI Ma'arif Kumpulrejo dilaksanakan sesuai dengan prosedur yang ada, kegiatan diawali dnegan melaksanakan rapat pertemuan yang membahas ada permasalahan apa saja di kelas, 
selanjutnya ditentukan solusi yang tepat dalam mengatasi permasalahan tersebut, solusi tersebut disusun dengan rinci dalam sebuah RPP yang dibahas dan disusun bersama. Selanjutnya ada pertemuan yang melibatkan guru model, siswa dan para guru lainnya serta komite untuk mengaplikasikan apa yang sudah dirancang pada pertemuan sebelumnya, dalam proses pelaksanaan ada beberapa hal yang perlu diperthatikan seperti penguasaan guru model terhadap rancangan pembelajaran, media yang harus disiapkan, serta siswa yang tidak boleh di setting terlebih dahulu, semuanya harus berjalan seperti pembelajaran biasa. Pelaksanaan Lesson Study selesai dilanjutkan dengan evaluasi terhadap apa yang dilaksanakan oleh guru model, evaluasi harus dilakukan dengan baik karena hal ini cukup berpotensi untuk meningkatkan kegiatan Lesson Study yang lebih baik dan sesuai tujuan"15

Pelaksanaan Lesson Studydi MI Ma'arif Kumpulrejo 02 memberikan sebuah harapan besar terhadap peningkatan kompetensi pedagogik guru dalam melaksanakan kewajiban seorang pendidik untuk mewujudkan pendidikan yang berdasarkan aturan kurikulum pemerintah. Perubahan kebijakan kurikulum yang terjadi setiap periode pergantian pemimpin menuntut guru untuk suka cita menerima dan menyesuaikan segala aspek perubahan. Pelaksanaan Lesson Study dilakukan secara berkala menyesuaikan kebutuhan dan kemampuan para guru untuk berkumpul dalam kegiatan tersebut. Kegiatan Lesson Study dilakukan untuk memberikan pemahaman dan informasi tentang menyelesaikan sebuah masalah pembelajaran di kelas dan menambah wawasan tentang pengembangan pembelajaran yang lebih variatif.

3. Implikasi Lesson Study terhadap peningkatan Kompetensi Pedagogik Guru

Kompetensi itu mutlak dibutuhkan guru, hal ini dikarenakan kompetensi merupakan sebuah upaya membekali guru dalam menghadapi persoalan-persoalan di lapangan. Kompetensi pedagogik adalah salah satu kompetensi

yang wajib dimiliki oleh seorang guru terkait dengan disiplin ilmu yang dimilikinya. Perkembangan zaman dan teknologi yang sangat cepat menuntut guru untuk membekali dirinya dengan ilmu-ilmu yang baru, maka dapat dipastikan guru akan dihargai oleh peserta didiknya.

Kepala sekolah meningkatkan kompetensi guru dengan memfasilitasi dengan menyusun program Lesson Study sebagai upaya peningkatan kualitas mutu lembaga pendidikan.

"Saat ini bukan saatnya guru berdiam diri merespon perubahan zaman, akan tetapi guru harus mau dan mampu untuk mengikuti trend di kalangan peserta didik.

${ }^{15}$ Wawancara dengan Ibu TM selaku guru dan bendahara BOS pada tanggal 11 Desember 2019. 
Guru tidak hanya dituntut belajar melalui sebuah buku. Justru pengalamanpengalaman nyata yang dialami. Guru perlu diabadikan dan dibagikan kepada teman sejawat untuk mendapatkan solusi dan inovasi dalam menyelasaikan sebuah permasalahan baik di dalam peserta didik maupun guru itu sendiri”. ${ }^{16}$

Guru sebagai pendidik tentunya memiliki potensi bidang manajerial. Bagaimana guru memahami kompetensi yang dimilikinya ini sering tidak dilakukan. Sebagai pribadi yang terus belajar dan berkembang guru seharusnya paham betul akan potensi yang dimilikinya.

Pengintegrasian Lesson Study dengan kurikulum 2013 di Madrasah dapat dikembangkan dari tingkat manajemen dan metode melalui kebijakan membangun jaringan yang melibatkan para pakar Teknologi, Praktisi Pendidikan, Penulis dan Lembaga yang terkait dengan pendidikan ataupun melibatkan peran aktif guru untuk mengenalkan konsep Lesson Study dalam proses kegiatan belajar mengajar sebagai salah satu model pembelajaran yang diterapkan di kelas. Integrasi Lesson Study dalam kurikulum 2013 dapat meningkatkan pencapaian tujuan pendidikan di lingkungan Madrasah.

Mengimplementasikan Lesson Study dalam kurikulum 2013 adalah sebagai upaya meningkatkan kompetensi pedagogik guru, sehingga dibutuhkan rancangan dalam menetapkan program - program Lesson Study di agenda kegiatan sekolah. Sekolah harus memberikan motivasi kepada para guru untuk melaksanakan tugasnnya dengan baik, para guru perlu ditumbuhkan semangat peningkatan kompetensi pedagogik. Sehingga ada kesadaran terhadap kegiatan peningkatan kompetensi pedagogik, sehingga guru harus melaksanakan dengan penuh tanggung jawab, bukan hanya sekedar menggugurkan kewajiban mengikuti sebuah kegiatan.

\section{B. DAYA DUKUNG LESSON STUDY TERHADAP KOMPETENSI PEDAGOGIK GURU di MI MA'ARIF KUMPULREJO 02}

1. Daya Dukung Lesson Study pada Kompetensi Pedagogik Guru yang Meningkat

Daya dukung peningkatan persiapan pembelajaran akan mendorong guru sebelum mengajar akan mempersiapkan RPP, lembar kerja siswa sehingga guru akan lebih cakap dan mampu menguasai karakteristik peserta didik dari aspek fisik, moral, spiritual, sosial, kultural, emosional, dan intelektual. Indikator ini terlihat saat peneliti melakukan wawancara terhadap kepala sekolah berkenaan dengan kinerja para guru MI Ma'rif Kumpulrejo 02: 2019.

${ }^{16}$ Wawancara dengan Ibu IRN kepala sekolah MI Ma'arif Kumpulrejo 02 pada tanggal 3 Desember 
"Berdasarkan hasil monitoring terhadap para guru di MI Ma'arif Kumpulrejo 02, para guru mampu memahami karakteristik peserta didik yang berkaitan dengan aspek fisik, intelektu al, sosial-emosional, moral, spiritual, dan latar belakang sosial-budaya, mampu mengidentifikasi potensi peserta didik dalam mata pelajaran yang diampu. Hal ini terlihat dengan penyusunan laporan hasil belajar siswa, mengidentifikasi bekal-ajar awal peserta didik dalam mata pelajaran yang diampu, serta mampu mengidentifikasi kesulitan belajar peserta didik dalam mata pelajaran yang diampu." 17

Berdasarkan fakta dilapangan dari hasil wawancara dan dokumen tertulis, ada beberapa pencapaian yang didapatkan dari hasil kegiatan Lesson Study. Berdasarkan observasi di lapangan berupa dokumen dan wawancara, guru di MI Ma'arif Kumpulrejo 02 sudah menguasai karakteristik peserta didik dari aspek fisik, moral, spiritual, sosial, kultural, emosional, dan intelektual, sebagaimana yang disampaikan kepala sekolah:

“Guru MI Ma'arif Kumpulrejo 02 mampu memberikan respon timbal balik terhadap individu dengan berbagai karakteristiknya, setiap anak melalui setiap tingkat, tetapi kecepatannya berbeda-beda. Namun Guru di MI Ma'arif Kumpulrejo 02 mampu mengatasi dan memberikan umpan balik terhadap setiap karakteristik anak yang berbeda-beda."

Guru sekolah dasar harus mampu mengidentifikasi potensi, pengetahuan awal dan mendiagnosis kesulitan peserta didik sehingga pembelajaran lebih bermakna, serta cukup menguasai teori belajar dan prinsip-prinsip pembelajaran yang mendidik, menyelenggarakan Pembelajaran yang mendidik, berkomunikasi secara efektif, empatik, dan santun dengan peserta didik, menyelenggarakan penilaian dan evaluasi proses dan hasil belajar.

Dari hasil observasi dan wawancara penulis menemukan beberapa indikator yang sudah dipenuhi oleh guru MI Ma'arif Kumpulrejo 02 seperti menguasai teori belajar dan prinsip-prinsip pembelajaran yang mendidik, mampu mengembangkan kurikulum yang terkait dengan mata pelajaran yang diampu, serta telah menyelenggarakan pembelajaran yang mendidik.

Ada beberapa indikator yang belum maksimal dilakukan oleh guru di MI Ma'arif Kumpulrejo 02 seperti memanfaatkan teknologi informasi dan komunikasi untuk kepentingan pembelajaran, memfasilitasi pengembangan potensi peserta didik untuk mengaktualisasikan berbagai potensi yang dimiliki, serta kurang

${ }^{17}$ Wawancara dengan Ibu IRN kepala sekolah MI Ma'arif Kumpulrejo 02 pada tanggal 3 Desember 
mengembangkan media pembelajaran, akan tetapi guru sangat baik dalam berkomunikasi secara efektif, empatik, dan santun dengan peserta didik.

2. Daya Dukung Lesson Study terhadap Kemampuan Guru Menjawab Perkembangan Zaman

Kompetensi adalah sebuah bekal utama bagi seorang guru agar mampu mencetak generasi yang diharapkan di masa depan yang akan datang. Menurut panitia sertifikasi guru rayon 138 Universitas Sanata Dharma dijelaskan bahwa akibat dari masih banyaknya guru yang tidak menguasai kompetensi yang dipersyaratkan ditambah dengan kurangnya kemampuan untuk menggunakan TIK membawa dampak pada peserta dalam dua hal.

Pertama, peserta didik hanya terbekali dengan kompetensi yang sudah usang, akibatnya produk sistem pendidikan dan pembelajaran tidak siap terjun ke dunia kehidupan nyata yang terus berubah. Kedua pembelajaran yang diselenggarakan oleh guru juga kurang kondusif bagi tercapainya tujuan secara aktif, kreatif, inovatif, efektif dan menyenangkan karena tidak didukung oleh penggunaan teknologi pembelajaran yang modern dan handal.

Perubahan kurikulum yang merombak proses pembelajaran tentunya guru tidak bisa berdiam diri. Untuk belajar tentang HOTS sebagai tuntutan kurikulum 2013 saja sudah membutuhkan waktu, apalagi mencari materi yang sesuai dengan kehidupan sehari-hari yang tentunya harus melalui metode dan pendekatan scientific sebagai tuntutan kurikulum 2013. Sehingga wajib hukumnya guru melakukan literasi dan bertukar pengalaman dengan teman sejawat sebagai upaya peningkatan kualitas dan kompetensi diri. Sebagaimana yang disampaikan Ibu AL selaku guru model:

"Saat ini bukan saatnya guru berdiam diri merespon perubahan zaman, akan tetapi guru harus mau dan mampu untuk mengikuti trend di kalangan peserta didik. Guru tidak hanya dituntut belajar melalui sebuah buku. Justru pengalamanpengalaman nyata yang dialami guru perlu diabadikan dan dibagikan kepada teman sejawat untuk mendapatkan solusi dan inovasi dalam menyelasaikan sebuah permasalahan baik di dalam peserta didik maupun guru itu sendiri." 18

Kemampuan merespon perkembangan zaman adalah tugas utama seorang guru, mengingat pendidik itu harus di didik sesuai dengan zamannya, dan guru harus sadar bahwa zaman selalu berubah sesuai dengan segala perkembangan teknologi saat ini.

${ }^{18}$ Wawancara dengan Ibu AL kepala sekolah MI Ma'arif Kumpulrejo 02 pada tanggal 11 Desember 
3. Daya Dukung Lesson Study terhadap Tunjangan Guru

Program sertifikasi adalah sebagai upaya pemerintah untuk menciptakan guru yang professional dan menghasilkan guru-guru yang memiliki kompetensi unggul. Dengan kemajuan Iptek yang sangat cepat, maka harus dibarengi dengan kompetensi sangat cepat, maka harus dibarengi dengan kompetensi guru agar dapat membimbing siswa dalam menghadapi kemajuan IPTEK yang begitu cepat.

Sebagaimana yang disampaikan Kepala Sekolah MI Ma’arif Kumpulrejo 02 Salatiga :

"Sebagai upaya peningkatan kompetensi guru, pemerintah melakukan uji kompetensi guru (UKG). Hasil UKG ini dijadikan tolak ukur kompetensi yang dimiliki guru. Berdasarkan hasil uji kompetensi banyak guru yang tidak menguasai penggunaan teknologi informasi dan komunikasi (TIK). Sebagian besar masih menggunakan metode ceramah, walaupun kurikulum 2013 sudah berlaku tetapi untuk merubah kebiasaan sangatlah sulit. Dengan menggunakan ceramah guru merasa hebat dan memiliki power karena menguasai materi yang disampaikan kepada siswa. Sebagai agen belajar seharusnya guru perlu memfasilitasi peserta didik untuk belajar, mengembangkan pengetahuan, keterampilan, kretifitas, bakat dan minat siswa sehingga siswa siap menghadapi kehidupan nyata di masa yang akan datang. ${ }^{19}$

Berdasarkan analisis diatas dapat disimpulkan melalui program pelatihan aspek substansi Lesson Study, dikembangkan beberapa metode pembelajaran yang mampu merubah paradigma mengajar guru. Tahap pelaksanaan (do) yang memuat tahap simulasi mengajar langsung lebih memberikan gambaran mengenai adanya keragaman gaya dan cara mengajar guru yang dapat di prediksikan agar dapat memberikan intervensi yang memadai. Namun, pemahaman tersebut belum merubah banyak praktik mengajar dikarenakan memerlukan waktu dan bantuan yang lebih untuk mencapai perubahan yang diharapkan.

Sebagaiamana yang disampikan bahwa untuk menerima sertifikasi, seorang guru harus melalui proses Uji Kompetensi Guru yang dilaksanakan oleh pemerintah. Uji kompetensi pastinya akan menyesuaikan dengan perkembangan zaman, sehingga perlu persiapan dari awal tentang kompetensi yang perlu ditingkatkan menyesuaikan perkembangan zaman. Hak atas tunjangan guru atau sertifikasi adalah salah satu nafas segar bagi para pendidik, namun tunjangan ini diperoleh dengan proses yang tidak mudah, para pendidik harus melalui proses uji kompetensi. Berdasarkan hasil wawancara disimpulkan bahwa guru MI Ma'arif

${ }^{19}$ Wawancara dengan Ibu IRN Kepala sekolah MI Ma'arif Kumpulrejo 02 Salatiga pada tanggal 3 Desember 2019. 
Kumpulrejo merasa program lesson study yang telah dilaksanakan memberikan dampak atas proses dalam menerima hak tunjangan pendidik. Hal ini dapat dilihat dari beberapa guru MI Ma'arif Kumpulrejo 02 yang telah menerima hak tunjangan.

4. Daya Dukung Lesson Study terhadap Kompetensi Lulusan

Kompetensi Lulusan dalam bentuk kualitas yang harus dimiliki oleh siswa yang telah menyelesaikan pendidikan pada satuan pendidikan pada jenjang tertentu. Peningkatan kompetensi lulusan adalah akibat dari kompetensi guru yang mampu memberi rangsangan kepada siswa untuk meningkatkan minat belajar, pemberian motivasi belajar, pemberian Reward and Punishment kepada siswa, sehingga dengan kompetensi yang unggul pada guru akan memiliki dampak terhadap kompetensi lulusan.

Kemampuan guru menggunakan informasi hasil penilaian dan evaluasi untuk menentukan ketuntasan belajar. menggunakan informasi hasil penilaian dan evaluasi untuk merancang program remedial dan pengayaan, mengkomunikasikan hasil penilaian dan evaluasi kepada pemangku kepentingan serta memanfaatkan informasi hasil penilaian dan evaluasi pembelajaran untuk meningkatkan kualitas pembelajaran maka akan tercipta kualita kompetensi lulusan yang terbaik dengan dukungan kompetensi guru yang sesuai dengan indikator yang sudah terlihat.

5. Daya Dukung Lesson Study terhadap Kualitas Lembaga Pendidikan

Meningkatnya kompetensi guru membangun atmosfer akademik di dalam kelas dan lembaga pendidikan. Dengan adanya kolaborasi antara guru satu dengan guru yang lain mengakibatkan adanya sinergi posituf yang berdampak pada peningkatan kualitas lembaga pendidikan. Hal ini dilihat dari pencapaian akreditasi sekolah yang mendapat predikat A serta bertambahnya jumlah siswa sebagai wujud kepercayaan masyarakat terhadap lembaga pendidikan di MI Ma'arif Kumpulrejo 02.

Kegiatan Lesson Study telah mampu menyediakan berbagai kegiatan pembelajaran untuk mendorong peserta didik mencapai prestasi secara optimal dan menyediakan berbagai kegiatan pembelajaran untuk mengaktualisasikan potensi peserta didik termasuk kreativitasnya. Selain itu dalam pelaksanaannya guru memaksimalkan untuk memanfaatkan teknologi informasi dan komunikasi dalam pembelajaran yang diampu. Dengan konsep program yang seperti itu maka kualitas lembaga pendidikan akan sejalan untuk menjadi lebih baik, hal ini karena pondasi dari lembaga tersebut sudah dibekali dengan kompetensi yang baik. 


\section{KENDALA PELAKSANAAN LESSON STUDY TERHADAP DAYA DUKUNG KOMPETENSI PEDAGOGIK di MI MA'ARIF KUMPULREJO 02}

1. Kurangnya Motivasi Guru dalam Mengembangkan Program Lesson Study

Tujuan meningkatkan kualitas pendidikan sesuai cita-cita pemerintah melalui Lesson Study adalah salah satu bentuk usaha untuk membantu pendidik memperbaiki kualitas mengajar dan meningkatkan karir atau profesinya. Dengan mendorong mereka untuk selalu bekerja sama antara mereka sendiri, akan tetapi selama ini belum tercapai melalui berbagai jenis pelatihan lain.

Beberapa hal yang menyebabkan para Guru kurang termotivasi dalam hal mengembangkan program pelatihan Lesson Study adalah sebagai berikut:

a. Perencanaan dan pelaksanaan pelatihan tidak mendukung terhadap pencapaian tujuan;

b. Materi pelatihan tidak sesuai dengan kebutuhan pendidik;

c. Implementasi hasil pelatihan oleh pendidik dalam kelas masih kurang maksimal;

d. Lemahnya sistem monitoring dan evaluasi implementasi hasil pelatihan oleh pendidik, baik oleh pengawas, kepala sekolah, atau pihak pejabat di Kementerian.

e. Kurangnya kesepamahan persepsi para guru tentang Lesson Study, dimana Lesson Study dimaksudkan untuk meningkatkan kualitas pembelajaran bukan menilai guru.

2. Pendanaan Program Lesson Study di MI Ma'arif Kumpulrejo 02

Kegiatan Lesson Study tidak terlepas dari kebutuhan dana untuk mensukseskan kegiatan tersbut, hal ini berkaitan dengan ada beberapa berkas yang harus digandakan serta konsumsi selama kegiatan, mengingat kegiatan ini tidak dapat telaksana hanya dalam satu waktu, tahap pelaksanaan Lesson Study minimal adalah dua kali pertemuan, yaitu waktu perencanaan dan waktu pelaksanaan. Dan tidak menutup kemungkinan saat mendatangkan tamu dari pakar pendidikan untuk masuk dalam proses Lesson Study maka harus menyediakan biaya administrasi transport untuk pemateri.

Adapun hasil wawancara dengan Bendahara MI Ma'arif Kumpulrejo 02 Kota Salatiga berkenaan dengan dana kegiatan Lesson Study :

"Keuangan dalam melaksanakan kegiatan pelatihan mandiri di tingkat lembaga pendidikan Ma'arif cukup terbatas, mengingat dana BOS tidak cukup banyak untuk mendukung kegiatan Lesson Study, sehingga dalam pelaksanaannya 
bendahara hanya mampu memberikan dana sebatas untuk konsumsi dan perlengkapan yang dibutuhkan"20

Kurangnya pendanaan dalam kegiatan Lesson Study di MI Ma'arif Kumpulrejo 02 adalah salah satu cerminan bahwasanya kegiatan yang tidak didukung dengan dana yang sesuai akan menghambat laju pelaksanaan kegiatan tersebut, dana yang dibutuhkan dalam kegiatan ini berupa biaya konsumsi, biaya pengadaan materi, biaya media pembelajaran atau biaya yang digunakan untuk menghadirkan pemateri. dengan tidak maksimalnya dukungan terhadap kegiatan tersebut akan berdampak pada hasil yang diharapkan yaitu peningkatan kompetensi pedagogik guru. Sehingga perlu adanya koordinasi yang baik antara kepala sekolah, komite dan kementerian Agama dalam menyelesaikan permasalahan berkenaan pendanaan kegiatan Lesson Study.

3. Sarana dan Prasarana di MI Ma'arif Kumpulrejo 02 Kurang lengkap

Kendala sarana dan prasarana menyebabkan guru MI Ma'arif Kumpulrejo 02 belum maksimal dalam memfasilitasi pengembangan potensi peserta didik untuk mengaktualisasikan berbagai potensi yang dimiliki dan belum maksimal dalam memanfaatkan hasil penilaian dan evaluasi untuk kepentingan pembelajaran.

4. Sulitnya Penyusunan Jadwal Pelaksanaan Program Lesson Study di MI Ma'arif Kumpulrejo 02

Menyusun jadwal kegiatan yang melibatkan seluruh dewan guru dan pihak terkait tidaklah mudah, mengingat kesibukan para dewan guru khususnya kepala madrasah sangat padat dengan agenda rapat dan pertemuan di luar sekolah. Kesulitan menentukan jadwal baik waktu pertemuan koordinasi persiapan, pelaksanaan Lesson Study, maupun refleksi dan menyusun pertemuan program selanjutnya. Sehingga perlu adanya komitmen yang kuat antar semua pihak untuk melaksanakan kegiatan Lesson Study.

5. Pendokumentasi Kegiatan Lesson Study di MI Ma'arif Kumpulrejo 02 Tidak Lengkap

Kegiatan tanpa dokumentasi yang baik hanya akan menyisakan sesuatu yang bersifat sesaat, sebagai gambaran saat penyusunan RPP di MI Ma'arif Kumpulrejo 02 tidak terdokumentasikan dengan baik, maka perencanaan yang sudah dilaksanakan sebelumnya hanya menjadi koleksi untuk guru model yang melaksanakan kegiatan tersebut, hal ini dikarenakan setelah pelaksanaan Lesson Study tidak dilanjutkan dengan menyusun laporan kegiatan setiap program Lesson

${ }^{20}$ Wawancara dengan Ibu AK selaku bendahara BOS MI Ma'arif Kumpulrejo 02 pada tanggal 11 Desember 2019. 
Study. Sehingga file RPP yang dirancang tersimpan di flash disk dan hard file yang suatu saat akan tidak diketahui keberadaannya.

Untuk langkah selanjutnya, seharusnya setiap kegiatan yang dilaksanakan harus ada laporan pertanggungjawabannya untuk mempermudah melihat progress peningkatan dari hasil program Lesson Study yang sudah dilaksanakan beberapa tahun terakhir. Selain itu dengan adanya dokumentasi yang baik akan mempermudah memperoleh dana dari kementerian karena ada bukti fisik bahwa MI Ma'arif telah melakukan upaya peningkatan kompetensi pedagogik terhadap guru.

6. Kurangnya Daya Dukung Yayasan dan Kementerian Agama

Pelaksanaan program Lessson Study harus didukung oleh beberapa pihak, bukan hanya keterlibatan kepala sekolah dan dewan guru yang mampu mewujudkan tujuan program Lesson Study di MI Ma'arif Kumpulrejo. Adanya kolaborasi dari beberapa pihak adalah salah satu kunci tercapainya tujuan program Lesson Study dalam lembaga pendidikan. Kendala yang dihadapi oleh MI Ma'arif Kumpulrejo 02 salah satunya yaitu kurangnya kolaborasi dengan pakar pendidikan baik di lingkungan Dinas Pendidikan, Kementerian Agama maupun praktisi pendidikan seperti Dosen dan Mahasiswa serta Komunitas belajar seperti pakar IT di bidang pendidikan untuk hadir pada saat perencanaan.

"Pada tahap perencanaan (plan) sangat dibutuhkan para praktisi dan pakar bidang pendidikan untuk hadir saat tahap perencanaan, karena dengan adanya kolaborasi antar praktisi pendidikan dan para dewan guru akan meningkatkan kinerja dalam menyusun sebuah rancangan pembelajaran yang lebih operasional, karena didukung dengan banyak ide yang tertuang dalam pertemuan tersebut. ${ }^{21}$

Untuk melaksanakan kegiatan Lesson Study di MI Ma'arif Kumpulrejo 02 Salatiga, perlu pendampingan intensif dan berkelanjutan, karena pelaksanaan Lesson Study di MI Ma'arif Kumpulrejo 02 masih perlu pendampingan lebih lanjut dalam pembuatan RPP sesuai kurikulum 2013 dengan mengingat urgensi pendidikan karakter yang terintegrasi dalam mata pelajaran. Lesson Study harus dikembangkan dengan melibatkan guru-guru, serta pakar dan praktisi pendidikan dari instansi lain untuk menambah khazanah wawasan metode dan strategi pembelajaran yang lebih kompleks.

7. Pendanaan Program Lesson Study di MI Ma'arif Kumpulrejo 02

Kegiatan Lesson Study tidak terlepas dari kebutuhan dana untuk mensukseskan kegiatan tersbut, hal ini berkaitan dengan ada beberapa berkas yang

${ }^{21}$ Wawancara dengan Ibu AL selaku guru model di MI Ma'arif Kumpulrejo 02 Salatiga pada tanggal 11 Desember 2019. 
harus digandakan serta konsumsi selama kegiatan, mengingat kegiatan ini tidak dapat telaksana hanya dalam satu waktu, tahap pelaksanaan Lesson Study minimal adalah dua kali pertemuan, yaitu waktu perencanaan dan waktu pelaksanaan. Dan tidak menutup kemungkinan saat mendatangkan tamu dari pakar pendidikan untuk masuk dalam proses Lesson Study maka harus menyediakan biaya administrasi transport untuk pemateri.

Adapun hasil wawancara dengan Bendahara MI Ma'arif Kumpulrejo 02 Kota Salatiga berkenaan dengan dana kegiatan Lesson Study :

"Keuangan dalam melaksanakan kegiatan pelatihan mandiri di tingkat lembaga pendidikan Ma'arif cukup terbatas, mengingat dana BOS tidak cukup banyak untuk mendukung kegiatan Lesson Study, sehingga dalam pelaksanaannya bendahara hanya mampu memberikan dana sebatas untuk konsumsi dan perlengkapan yang dibutuhkan"22

Kurangnya pendanaan dalam kegiatan Lesson Study di MI Ma'arif Kumpulrejo 02 adalah salah satu cerminan bahwasanya kegiatan yang tidak didukung dengan dana yang sesuai akan menghambat laju pelaksanaan kegiatan tersebut, dana yang dibutuhkan dalam kegiatan ini berupa biaya konsumsi, biaya pengadaan materi, biaya media pembelajaran atau biaya yang digunakan untuk menghadirkan pemateri. dengan tidak maksimalnya dukungan terhadap kegiatan tersebut akan berdampak pada hasil yang diharapkan yaitu peningkatan kompetensi pedagogik guru. Sehingga perlu adanya koordinasi yang baik antara kepala sekolah, komite dan kementerian Agama dalam menyelesaikan permasalahan berkenaan pendanaan kegiatan Lesson Study.

8. Sarana dan Prasarana di MI Ma'arif Kumpulrejo 02 Kurang lengkap

Kendala sarana dan prasarana menyebabkan guru MI Ma'arif Kumpulrejo 02 belum maksimal dalam memfasilitasi pengembangan potensi peserta didik untuk mengaktualisasikan berbagai potensi yang dimiliki dan belum maksimal dalam memanfaatkan hasil penilaian dan evaluasi untuk kepentingan pembelajaran.

9. Sulitnya Penyusunan Jadwal Pelaksanaan Program Lesson Study di MI Ma'arif Kumpulrejo 02

Menyusun jadwal kegiatan yang melibatkan seluruh dewan guru dan pihak terkait tidaklah mudah, mengingat kesibukan para dewan guru khususnya kepala madrasah sangat padat dengan agenda rapat dan pertemuan di luar sekolah. Kesulitan menentukan jadwal baik waktu pertemuan koordinasi persiapan, pelaksanaan Lesson Study, maupun refleksi dan menyusun pertemuan program

${ }^{22}$ Wawancara dengan Ibu AK selaku bendahara BOS MI Ma'arif Kumpulrejo 02 pada tanggal 11 Desember 2019. 
selanjutnya. Sehingga perlu adanya komitmen yang kuat antar semua pihak untuk melaksanakan kegiatan Lesson Study.

10. Pendokumentasi Kegiatan Lesson Study di MI Ma'arif Kumpulrejo 02 Tidak Lengkap

Kegiatan tanpa dokumentasi yang baik hanya akan menyisakan sesuatu yang bersifat sesaat, sebagai gambaran saat penyusunan RPP di MI Ma'arif Kumpulrejo 02 tidak terdokumentasikan dengan baik, maka perencanaan yang sudah dilaksanakan sebelumnya hanya menjadi koleksi untuk guru model yang melaksanakan kegiatan tersebut, hal ini dikarenakan setelah pelaksanaan Lesson Study tidak dilanjutkan dengan menyusun laporan kegiatan setiap program Lesson Study. Sehingga file RPP yang dirancang tersimpan di flash disk dan hard file yang suatu saat akan tidak diketahui keberadaannya.

Untuk langkah selanjutnya, seharusnya setiap kegiatan yang dilaksanakan harus ada laporan pertanggungjawabannya untuk mempermudah melihat progress peningkatan dari hasil program Lesson Study yang sudah dilaksanakan beberapa tahun terakhir. Selain itu dengan adanya dokumentasi yang baik akan mempermudah memperoleh dana dari kementerian karena ada bukti fisik bahwa MI Ma'arif telah melakukan upaya peningkatan kompetensi pedagogik terhadap guru.

11. Kurangnya Daya Dukung Yayasan dan Kementerian Agama

Pelaksanaan program Lessson Study harus didukung oleh beberapa pihak, bukan hanya keterlibatan kepala sekolah dan dewan guru yang mampu mewujudkan tujuan program Lesson Study di MI Ma'arif Kumpulrejo. Adanya kolaborasi dari beberapa pihak adalah salah satu kunci tercapainya tujuan program Lesson Study dalam lembaga pendidikan. Kendala yang dihadapi oleh MI Ma'arif Kumpulrejo 02 salah satunya yaitu kurangnya kolaborasi dengan pakar pendidikan baik di lingkungan Dinas Pendidikan, Kementerian Agama maupun praktisi pendidikan seperti Dosen dan Mahasiswa serta Komunitas belajar seperti pakar IT di bidang pendidikan untuk hadir pada saat perencanaan.

Pada tahap perencanaan (plan) sangat dibutuhkan para praktisi dan pakar bidang pendidikan untuk hadir saat tahap perencanaan, karena dengan adanya kolaborasi antar praktisi pendidikan dan para dewan guru akan meningkatkan kinerja dalam menyusun sebuah rancangan pembelajaran yang lebih operasional, karena didukung dengan banyak ide yang tertuang dalam pertemuan tersebut. ${ }^{23}$

${ }^{23}$ Wawancara dengan Ibu AL selaku guru model di MI Ma'arif Kumpulrejo 02 Salatiga pada tanggal 11 Desember 2019. 
Untuk melaksanakan kegiatan Lesson Study di MI Ma'arif Kumpulrejo 02 Salatiga, perlu pendampingan intensif dan berkelanjutan, karena pelaksanaan Lesson Study di MI Ma'arif Kumpulrejo 02 masih perlu pendampingan lebih lanjut dalam pembuatan RPP sesuai kurikulum 2013 dengan mengingat urgensi pendidikan karakter yang terintegrasi dalam mata pelajaran. Lesson Study harus dikembangkan dengan melibatkan guru-guru, serta pakar dan praktisi pendidikan dari instansi lain untuk menambah khazanah wawasan metode dan strategi pembelajaran yang lebih kompleks.

\section{KESIMPULAN}

Berdasarkan penelitian yang telah dilakukan, maka dapat diambil kesimpulan bahwa Implementasi Lesson Study pada Integrasi Kurikulum 2013 sebagai Daya Dukung Kompetensi Pedagogik Guru MI Ma'arif Kumpulrejo 02 Kota Salatiga sebagai berikut :

1. Implementasi Lesson Study di MI Ma'arif Kumpulrejo 02 dilaksanakan dengan melakukan perencanaan untuk mengetahui masalah yang dialami guru dalam proses pembelajaran, dalam kegiatan tersebut juga menentukan solusi yang digunakanan dalam menyelesaikan permasalahan yang terjadi, selanjutnya kegiatan kedua yaitu melaksanakan hasil rancangan pembelajaran berdasarkan rancangan yang telah disusun sebagai solusi permasalahan yang dialami oleh guru. Kegiatan yang terakhir yaitu mengevaluasi dan merefleksi hasil pengamatan pada kegiatan tahap kedua.

2. Daya dukung program Lesson Study terhadap kompetensi pedagogik guru mampu membentuk guru yang menguasai karakteristik peserta didik pada aspek fisik, moral, spiritual, sosial, kultural, emosional, dan intelektual. Program Lesson Study salah satu wadah bagi guru dalam menjawab perkembangan zaman yang semakin kompleks, Lesson study mampu menjadi daya dukung bagi guru dalam memperjuangkan kesehteraannya serta membantu guru dalam menjawab tantangan zaman dan sebagai daya dukung terhadap kompetensi lulusan serta kualitas lembaga pendidikan.

3. Kendala yang terjadi dalam proses Lesson Study di MI Ma'arif Kumpulrejo 02 Salatiga adalah sebagai berikut: Kurangnya motivasi guru dalam mengembangkan program Lesson Study; Kurangnya Pendanaan program Lesson Study di MI Ma'arif Kumpulrejo 02; Sarana dan Prasarana di MI Ma'arif Kumpulrejo 02 Kurang lengkap; Sulitnya Penyusunan jadwal pelaksanaan program Lesson Study di MI Ma'arif Kumpulrejo 02; Pendokumentasian kegiatan Lesson Study di MI Ma'arif Kumpulrejo 02 Kurang lengkap; Kurangnya daya dukung Yayasan dan Kementerian Agama. 


\section{DAFTAR PUSTAKA}

Andini Deassy May, Endang Supardi, "Kompetensi Pedagogik Guru Terhadap Efektivitas Pembelajaran Dengan Variabel Kontrol Latar Belakang Pendidikan Guru”. Jurnal Pendidikan Manajemen Perkantoran. Vol. 1 No.2 (2018), 1-7.

Budiono Saputro,"Manajemen Penelitian Pengembangan research \& development bagi penyusun tesis dan disertasi", Yogyakarta: Aswaja Pressindo,2011.8.

Daryanti, dkk. "Peningkatan Kemampuan penalaran ilmiah melalui model pembela jaran Inkuiri terbimbing pada materi sistem pernapasan manusia”. Jurnal pendidikan matematika dan sains, Vol. 3, No 2 (2015), 163-168.

Dwi Ariyani, Guru Sadar Tantangan Zaman, Sukoharjo: CV. Farishma Indonesia, 2018.

Hartati, T.A W., dkk. "Perbandingan Potensi Model Pembelajaran Berbasis Kontruktivis dalam prosiding memberdayakan keterampilan proses sains dan hasil belajar kognitif siswa berkemampuan akademik rendah". Prosiding Seminar Nasional XII Pendidikan Biologi FKIP UNS 2015, Universitas Negeri Surakarta.

https://ayomadrasah .blogspot.com. diakses pada tanggal 25 November 2018: pukul: 10.30.

Ibrohim, Apa, Mengapa dan Bagaimana Lesson Study: Pola Alternatif untuk meningkatkan Efektivitas Praktik Pengalaman Lapangan (PPL) Mahasiswa Calon Pendidik. Makalah disajikan dalam Workshop Pembimbing PPL Berbasis Lesson Study di FS UM, Tanggal 26 Januari 2010.

Jasmaniah, Asrul Karim, Zulkifli, "Implementasi Pembelajaran Bilangan Dan Operasinya Melalui Lesson Study (Pengalaman mengimplementasikan Lesson Study pada perkuliahan)", Jurnal Pendidikan Almuslim, Vol. 1, No.1 (2013), 15-17.

Ketut suma, "Implementasi Lesson Study Sebagai Upaya Pembinaan Profesionalisme Guru MIPA SMA di Kabupaten Bangli”, Seminar Nasional FMIPA UNDISKHA III Tahun 2013, Universitas Pendidikan Ganesha.

Lewis Catherine C., "Improving mathematics instruction thourgh Lesson Study: a theorical model and North American case", Journal of Mathematics Teacher Education, Vol. 12, No. 2 (2009), 285-30.

Lexy Moelong, Metode Penelitian Kualitatif, Bandung: PT Remaja Rosdakarya, 2009.

Mahmudi Ali, "Mengembangkan Kompetensi Guru Melalui Lesson Study", Jurnal Forum Kependidikan FKIP UNSRI. Vol 28, No. 2 (2009), 4.

Marsigit, "Mathematics Teachers' Profesional Development through Lesson Study in Indonesia", Eurasia Journal of Mathematics, Science \& technology Education, Vol 3, No.2 (2007), 141-144.

Munthe Bermawi. Desain Pembelajaran. Yogyakarta: PT Insan Pustaka Madani. 2009, 115-120.

Ni'am, A. Membangun Profesionalisme Guru. Jakarta: ELSAS. 2006, 85-88.

Ninik Sumiarsi, Analisis Kompetensi Pedagogik dan Pengembangan Pembelajaran Guru SD Negeri 041 Tarakan", Jurnal Pendidikan dan Pengembangan Pendidikan, Vol. 3, no. 1(2015), 99-104. 
Ono Yumiko and Johana Ferreira, "A case study of continuing teacher professional development through Lesson Study in South Africa. South African Journal of Educati, Vol. 30, No.2 ( 2010), 59-74.

Permendikbud No.16 Tahun 2017 tentang Standar Kompetensi Pedagogik Guru di SD/MI, SMP/MTs, SMA/MA, dan SMK/MAK.

Permendiknas Nomor 16 Tahun 2007 tentang Standar Kualifikasi Akademik dan Komptensi Guru. Jakarta: Asa Mandiri.

P.Purnomo, "Implementing the School-Based Lesson Study in Elementary Schools", Jurnal Prime Edukasi, Vol. 5, No. 2 (2017), 160-171.

Prayekti \& Rasyimah, "Lesson Study For Improving The Achievement Of Science For Student In Elementary School”, Jurnal Pendidikan dan Kebudayaan, Vol. 18, No. 1 (Maret 2012), 54-64.

Prof. Dra. Herawati Susilo, M.Sc., Ph. D, Lesson Study Sebagai Sarana Meningkatkan Kompetensi Pendidik, Makalah disajikan dalam seminar dan Lokakarya PLEASE 2013 di Sekolah Tinggi Theologi Aletheia, tanggal 9 Juli 2013.

Sugiyono, Metode Penelitian Pendidikan: Pendekatan, Kuantitatif, Kualitatif, dan R7D, Bandung: alfabeta, 2014.

Tedjawati, "Peningkatan Kompetensi Guru melalui Lesson Study: kasus di Kabupaten Bantul”, Jurnal Pendidikan dan Kebudayaan, Vol. 17, No. 4, (Juli 2011), 480489.

Undang-undang No. 14 tahun 2005 Pasal 10 ayat (1) tentang Guru dan Dosen.

Undang-Undang Republik Indonesia Nomor 14 Tahun 2005 tentang Guru dan Dosen.

Wawancara dengan Ibu IRN Kepala sekolah MI Ma'arif Kumpulrejo 02 Salatiga pada tanggal 3 Desember 2019.

Wawancara dengan bapak AK selaku bendahara BOS MI Ma'arif Kumpulrejo 02 pada tanggal 11 Desember 2019

Wawancara dengan Ibu AL selaku guru model di MI Ma'arif Kumpulrejo 02 Salatiga pada tanggal 11 Desember 2019.

Wawancara dengan Ibu TM selaku guru dan bendahara BOS di MI Ma'arif Kumpulrejo 02 Salatiga pada tanggal 11 Desember 2019.

Zubaidah Siti, "Makalah disampaikan pada pendidikan dan pelatihan Nasional dengan tema peningkatan Profesionalisme Guru melalui Kegiatan Lesson Study”, 22 April 2010 di Universitas Brawijaya Malang. 